\title{
Kömür Madenlerinde Radon Ölçümleri
}

\author{
Radon Measurements in Coal Mines
}

Mehmet Ertan KÜRKÇÜOĞLU, Havva AKGÖNÜL, Alaiddin YILMAZ

\begin{abstract}
ÖZET
Radon doğal bir radyasyon kaynağıdır. Kaçınılmaz olarak maruz kaldığımız doğal radyasyonun yarısından doğrudan sorumludur. Radon, A-sınıfı bir kanserojendir. İyonize radyasyon nedeniyle, kapalı mekânlarda meydana gelebilecek en büyük risklerden birisi, akciğer kanseri oluşumuyla ilişkilendirilen radon ve radon bozunma ürünlerinin solunması sonucu ortaya çıkar. Madenlerdeki radyolojik risk diğer işyerlerine göre daha büyüktür. Bu nedenle, atmosferik radon konsantrasyonunun belirlenmesine yönelik madenlerde yapılan ölçümler, maden çalışanlarının sağlı̆̆ını yakından ilgilendiren önemli bir konudur. Bu çalışmada, madencilik sektöründe radon ölçümlerinin gelişimi özetlenmekte, kömür madenleri özelinde dünya ve ülkemizdeki literatür incelenerek değerlendirilmektedir.
\end{abstract}

Anahtar Kelimeler: Radon, kömür madeni, radyolojik risk, madenci sağlı̆̆ı.

\section{ABSTRACT}

Radon is a natural radiation source. It is directly responsible for half of the natural radiation that we are inevitably taken. Radon is a Class-A carcinogen. Inhalation of radon and radon decay products, which is related to the aetiology of lung cancer, is one of the greatest risk from ionizing radiation that taken indoor environments. In general, the radiological risks in mines are greater than the risks in the other workplaces. Therefore, the subject concerning the measurement of atmospheric radon concentration in mines has a great importance and it is closely related to the health of mineworkers. In the present study, the development of radon measurements in the mining industry has been summarized. Then the radon measurements have been specifically investigated for coal mines and the related literature regarding Turkey and the other countries in the world have been evaluated.

Keywords: Radon, coal mine, radiological risk, miner health.

Dr. Öğr. Üyesi Mehmet Ertan KÜRKçÜoĞLU — Süleyman Demirel Üniversitesi, Fen Edebiyat Fakültesi, Isparta, Türkiye Assistant Prof. Mehmet Ertan KURKÇUOGLU - Suleyman Demirel University, Faculty of Arts and Sciences, Isparta, Turkey ORCID ID: 0000-0002-4694-1880 ertankurkcuoglu@sdu.edu.tr

Havva AKGÖNÜL —Süleyman Demirel Üniversitesi, Fen Bilimleri Enstitüsü, Isparta, Türkiye

Havva AKGONUL - Süleyman Demirel Üniversitesi, Graduate School of Natural and Applied Sciences, Isparta, Turkey ORCID ID: 0000-0002-7624-324X havvahepkarsi@gmail.com

Dr. Öğr. Üyesi Alaiddin YILMAZ - Zonguldak Bülent Ecevit Üniversitesi, Fen Edebiyat Fakültesi, Zonguldak, Türkiye Assistant Prof. Alaiddin YILMAZ - Zonguldak Bulent Ecevit University, Faculty of Arts and Sciences, Zonguldak, Turkey ORCID ID: 0000-0002-2595-0681_ayilmaz@beun.edu.tr 


\section{GIRIŞ}

86 atom numarası ile periyodik cetvelde $8 \mathrm{~A}$ grubunun en son elementi olan radon, radyoaktif bir soy gazdır. Birleşmiş Milletler Atomik Radyasyonun Etkileri Bilimsel Komitesi'nin (UNSCEAR: United Nations Scientific Committee on the Effects of Atomic Radiation) 2000 y1lındaki verilerine göre, doğal kaynaklı radyasyonlar nedeniyle dünya genelinde kişi başı maruz kalınan yıllık doz düzeyi ortalaması 2,4 mSv civarındadır ve bunun yaklaşık yarısını radon ( ${ }^{222} \mathrm{Rn}$ ) ve radonun bozunma ürünleri oluşturmaktadır [1].

Doğal olarak her yerde bulunan ve renksiz, kokusuz, tatsız bir gaz olan radon, bozunma ürünü olarak yayınladığ1 alfa parçacı̆̆ı sayesinde keşfedilmiştir. Radon; havadan yaklaşık 8 kat, hidrojenden ise 100 kat daha ağırdır. $-71^{\circ}$ C'de donarken 1 atm basınçtaki kaynama noktası -62 o C'dir [2]. Radon'un atomik yarıçapı $1,3 \times 10^{-10} \mathrm{~m}$ ve atomik kesitinin alanı $0,72 \times 10^{-10} \mathrm{~cm} 2$ 'dir. Yoğunluğu, 1 atmosfer basınçta $9,73 \mathrm{~g} / \mathrm{L}$ ve $273 \mathrm{~K}$ 'deki molar hacmi $50,5 \mathrm{~cm}^{3} /$ mol dür. Elektriksel iletkenliği yoktur, 1sıl iletkenliği ise 0,0000364 W/cmK değerinde olup çok düşüktür. Radonun öz 1sısı 0,091 J/gK dir [3].

Radon, ${ }^{228} \mathrm{U},{ }^{232} \mathrm{Th}$ ve ${ }^{235} \mathrm{U}$ bozunma serilerinden gelen üç doğal radyoizotopa sahiptir (Tablo 1). ${ }^{219} \mathrm{Rn}$ (aktinon), aktinyum serisinin, ${ }^{220} \mathrm{Rn}$ (toron), toryum serisinin ve ${ }^{222} \mathrm{Rn}$ ise uranyum bozunma serisinin bir ürünüdür. ${ }^{222} \mathrm{Rn}$ ve ${ }^{220} \mathrm{Rn}$, doğada genellikle birlikte bulunur. Bolluk ve yar1ömürlerine göre değerlendirildiğinde, insanların radyasyona maruz kalmaları açısından bu üç doğal radyoizotop içerisinde en tehlikelisi, 1600 yıl yarı-ömüre sahip radyum226 radyoçekirdeğinin bozunma ürünü olan ${ }^{222} \mathrm{Rn}$ 'dir. 3,82 günlük yarı-ömrü sonucunda $5,48 \mathrm{MeV}$ enerjili bir alfa-parçacığı ( $\alpha$-parçacığı) yayınlayan radon, polonyum218 radyoçekirdeğine bozunarak kısa yarı ömürlü radon ürünlerinin $\left({ }^{218} \mathrm{Po},{ }^{214} \mathrm{~Pb},{ }^{214} \mathrm{Bi}\right.$ ve $\left.{ }^{214} \mathrm{Po}\right)$ oluşumuna yol açar.

Uranyum ve toryum radyonüklidlerinin ana kaynağ 1 yerkabuğunu oluşturan kayalar ve topraktır. Farklı coğrafik bölgelere göre değişiklik göstermekle birlikte, yerkabuğundaki ${ }^{238} \mathrm{U}$ konsantrasyonu ortalamasının yaklaşık $2 \mathrm{ppm}$ olduğu tahmin edilmektedir [5]. Bu doğal radyoaktif elementlerin bozunması sonucu oluşan radon, kaya katmanlar1 arasından sızarak atmosfere ulaşır. Topraktan gelen radyum emanasyonunun yılda 2 milyar Curie ve yeraltı sularındaki potansiyelin yıllık 500 milyon Curie civarında olduğu düşünülmektedir [6]. Radon seviyelerinin; toprak gazında 18-180 kBq/m3, bina içi atmosferinde 11-300 Bq/ $\mathrm{m}^{3}$, okyanuslar üzerindeki hava tabakasında 0,02-0,2 Bq/ $\mathrm{m}^{3}$, mağaralarda $0,37-11 \mathrm{kBq} / \mathrm{m}^{3}$ ve havalandırması olmayan uranyum madenlerinde $37-3700 \mathrm{kBq} / \mathrm{m}^{3}$ aralığında değiştiği bildirilmiştir [3]. Toprakta bulunan ve yeraltı sularıyla taşınan radon gazı, difüzyon mekanizmaları vasıtasıyla bina içi ve bina dışındaki havaya karışır. Havadan daha ağır olan radon gazı, havalandırmanın zayıf olduğu kapalı mekânlarda zemine çökerek zamanla birikebilir [5].

Radon ölçümlerine yönelik ilk araştırmalar, madencilik sektöründeki gelişmelerle birlikte başlamıştır. Zamanla madenlerde, özellikle de uranyum madenlerinde çalışan işçilerde erken yaşta ölümlerin gözlenmesi dikkati çeken bir

Tablo 1: Radonun doğal radyoizotopları [4]

\begin{tabular}{c|c|c|c|c}
\hline Bozunma Serisi & Ana Çekirdek & Yarı-ömür (yıl) & Kararlı Çekirdek & Radyoizotop Yarı-Ömrü (s) \\
\hline Toryum & ${ }^{232} \mathrm{Th}$ & $1,4 \times 10^{10}$ & ${ }^{208} \mathrm{~Pb}$ & ${ }^{220} \mathrm{Rn}(\sim 56)$ \\
\hline Uranyum & ${ }^{238} \mathrm{U}$ & $4,5 \times 10^{9}$ & ${ }^{206} \mathrm{~Pb}$ & ${ }^{222} \mathrm{Rn}(\sim 330000)$ \\
\hline Aktinyum & ${ }^{235} \mathrm{U}$ & $7,1 \times 10^{8}$ & ${ }^{207} \mathrm{~Pb}$ & ${ }^{219} \mathrm{Rn}(\sim 4)$ \\
\hline
\end{tabular}


durum olmuştur. Bu hastalık, madenciler arasında "Dağ Hastalı̆ı̆” olarak nitelendirilmiş olsa da 1879 'da yapılan klinik araştırmalar bu rahatsızlı̆ıı asıl sebebinin akciğer tümörleri olduğunu göstermiştir. Bu gelişmelerin yanı sıra, 1896 yllında radyoaktivite fark edilmiş ve takiben 1899 yılında Ernest Rutherford tarafindan radon-220 radyoizotopu [7] ve 1900 yilında Friedrich Ernest Dorn tarafindan radon-222 radyoizotopu keşfedilmiştir [8]. 1901'de Elster ve Geitel tarafindan atmosferde radyonüklidlerin varlığı gösterilmiştir [9]. Günümüzde, atmosferde bulunan radyonüklidlerin büyük çoğunluğunun radon ve bozunma ürünleri olduğu bilinmektedir [10]. Radyoaktif radon elementinin keşfedilmesi ile çeşitli madenlerde radon yoğunlukları ölçülmeye başlanmış ve 1924 yılında Ludwig ve Lorenser tarafından, maden ocaklarında rastlanan akciğer kanserine, ocaklarda biriken radon gazının solunmasının neden olduğu ileri sürülmüş̧ür [11]. 1930'lara dek madenlerde yap1lan ölçümlerle radon düzeylerinin yüksek olduğu belirlenmiş ve çalışmalar, akciğer kanseri oluşumuyla madenlerdeki radon seviyesi arasındaki ilişki üzerine yoğunlaşmıştır. 1950 'lere kadar radonun akciğer kanserine neden olduğu görüşü yaygın bir biçimde kabul edilirken, 1951 yılında Rochester Üniversitesi'nden araştırmacılar akciğer kanseri tehlikesinin daha çok radon ürünlerinin yayınladığı alfa radyasyonuna maruz kalınmasından kaynaklanabileceğini öne sürmüşlerdir [12]. Bu görüş daha sonra yapılan çalışmalarla [13] da desteklenmiştir.

İyonlaştırıcı radyasyon canlı dokularla doğrudan etkileştiğinde, gözardı edilemeyecek büyüklükte bir enerji hücrelere aktarılır. Bunun sonucunda dokularda; ölüm, nesilden nesile geçen genetik değişiklikler ya da kanser gibi daha sonra ortaya çıkan etkiler gözlemlenebilmektedir. Radyasyonun biyolojik yapılar üzerinde meydana getirdiği en belirgin etkilerden biri hücre büyümesini baskılamasıdır. Ürünleri arasında $\alpha$-parçacığı bulunan radyoaktif element- ler solunum ve sindirim yoluyla vücuda alındığında, akciğer ve mide dokularını yüksek dozda radyasyona maruz bırakabilir [14]. Kimyasal olarak inert bir gaz olan radonun dokulardaki çözünürlüğü düşüktür. Akciğerlere alınan radonun bir kısmı solunum yoluyla dışarı atılabilir fakat kimyasal bakımdan aktif halde bulunan ve radyoaktif olan radon ürünleri, havadaki partiküllere tutunarak solunumla akciğer bronşlarına yerleşip bozunmaya devam edebilirler. Bu süreçte ortaya çıkan radyasyon, hücrelerin DNA yapılarını değiştirebilir ve akciğer kanserine neden olabilir [15]. 150 yil öncesine kadar nadir olarak rastlanan akciğer kanseri günümüzde, dünyada en sık görülen kanser türü haline gelmiştir [16]. Akciğer kanseri ve radon arasındaki ilişki üzerine yapılmış epidemiyolojik çalışmaların topluca analiz edildiği Uluslararası Radyolojik Korunma Komisyonu (ICRP: International Commission on Radiological Protection) raporu, radon ve bozunma ürünlerinin akciğer kanserine neden olduğunu kesin olarak ortaya koymuştur [17]. A.B.D. Çevre Koruma Ajansı (EPA: Environmental Protection Agency) ve Dünya Sağlık Örgütü (WHO: World Health Organisation) tarafindan "A sınıfı kanserojen madde" olarak derecelendirilen radon gazı, akciğer kanserine neden olan en tehlikeli maddeler listesinde sigaradan sonra ikinci sırada yer almaktadır [18, 19]. EPA, Amerika Birleşik Devletleri'nde bir yılda akciğer kanseri nedeniyle meydana gelen ölümlerin (157400 kişi) yaklaşık \%13,4’ünün (21100 kişi) radon gazı solunması nedeniyle olduğunu bildirmektedir [20]. Dünya Sağlık Örgütü’ne göre ise bu oranın yaşanılan bölgenin radon düzeyine bağlı olarak \%3 ile \%14 arasında değiştiği bildirmektedir [19].

Kapalı mekânlardaki radon kaynaklı sağılı risklerinin azaltılabilmesi amacıyla ülkeler (çeşitli ulusal ve uluslararası kuruluşlar vasıtasıyla) atmosferik radon düzeyleri için bazı limit değerler belirlemişlerdir. Ülkemizdeki radyasyon güvenliği konusundaki resmi çalışmalar, yasa ile yetkilendiri- 
Tablo 2: Çeşitli kuruluşlar tarafından kabul edilen bina içi atmosferik radon limitleri

\begin{tabular}{llrl}
\hline \multirow{2}{*}{ Organizasyon } & \multicolumn{2}{l}{ Tavsiye Edilen Limitler $\left(\mathrm{Bq} / \mathrm{m}^{\mathbf{3}}\right)$} & Kaynak \\
& Ev & İş yeri & {$[21]$} \\
\hline ICRP & $\leq 300$ & $\leq 1000$ & {$[19]$} \\
WHO & $\leq 100$ & & {$[22]$} \\
$\mathrm{AB}^{*}$ & $\leq 300$ & $\leq 1000$ & {$[23]$} \\
TAEK & $\leq 400$ & $\leq 1000$ & \\
\hline
\end{tabular}

*AB: Avrupa Birliği Komisyonu

len Türkiye Atom Enerjisi Kurumu (TAEK) tarafindan yürütülmektedir. TAEK ve küresel ölçekte referans alınan bazı organizasyonların ev ve iş yerleri için kabul ettiği limitler Tablo 2'de verilmektedir. Limit seviyesinin aşıldığı durumlarda, bina içi radon yoğunluğunu düşürücü önlemlerin alınması tavsiye edilmektedir. ICRP 2014 yılında yayınladığı 126 nolu raporla birlikte kapalı mekânlar için tavsiye ettiği limit düzeylerini yeniden düzenlemiş ve işletmeler için de yeni bir sınflandırmaya gitmiştir. Buna göre, madenler, mağaralar, metro istasyonları, tüneller v.b. gibi yer altındaki iş yerleri için $1000 \mathrm{~Bq} / \mathrm{m}^{3}$ lük limit benimsenirken toprak seviyesinin üstündeki kamu binaları, hastaneler, okullar, sinemalar, fabrikalar, dükkânlar, ofisler v.b. gibi halkın ortak kullandığı iş yerleri için meskenlerdeki limitin $\left(300 \mathrm{~Bq} / \mathrm{m}^{3}\right)$ baz alınması tavsiye edilmektedir [21]. TAEK ise iş yerlerini ayırmaksızın tüm iş yerlerindeki atmosferik radon limitini $1000 \mathrm{~Bq} / \mathrm{m}^{3}$ olarak kabul etmekte$\operatorname{dir}[23]$.

Sağlık üzerindeki olumsuz etkilerinin anlaşılmasıyla birlikte, meskenler ve iş yerleri için yürütülen radon ölçümlerinin sayısı günden güne artarak sürdürülmektedir. Sadece Kuzey Amerika'da yılda bir milyon civarında bina içi radon konsantrasyonu ölçümünün gerçekleştirildiği bildirilmektedir [6]. Dünya genelinde, meskenlerdeki atmosferik radon seviyesi $40 \mathrm{~Bq} / \mathrm{m}^{3}$ civarındadır. Ancak yer altı işletmeleri, yüksek radon birikiminin meydana gelebile- ceği alanlardır. Çek Cumhuriyeti'nde tünellerde yapılan bir çalışmada, $3,3 \mathrm{kBq} / \mathrm{m}^{3}$ düzeyine varan atmosferik radon yoğunlukları rapor edilmiştir [24]. Turizme açık mağaralar için İrlanda' da gerçekleştirilen bir araştırma, $260 \mathrm{~Bq} / \mathrm{m}^{3}$ ile $19,06 \mathrm{kBq} / \mathrm{m}^{3}$ arasında değişen radon konsantrasyonlarının ölçüldügünü bildirmektedir [25]. Diğer bir çalışmada, Macaristan'daki turist mağaraları için $21,1 \mathrm{kBq} / \mathrm{m}^{3}$ değerine ulaşan radon seviyeleri tespit edilmiştir [26]. Uranyum madenlerinde yapılan epidemiyolojik araştırmalar ise radon nedeniyle, en yüksek kanser riskine sahip meslek grubunun uranyum madencileri olduğunu göstermektedir [15]. Genelde, kömür madenlerindeki radon konsantrasyonları, diğer madenlere göre daha düşüktür. Radonun solunması sonucu maruz kalınacak yıllık etkin doz eşdeğeri (YEDE) ortalamasının; kömür madenleri için $0,7 \mathrm{mSv} / \mathrm{y} ı \mathrm{l}$ ve uranyum haricindeki diğer madenler için ise $2,7 \mathrm{mSv} / \mathrm{yll}$ olduğu kabul edilmektedir [1]. Buna rağmen, kömür madenleri için radyolojik olarak önemli seviyelerin saptandığı bazı çalışmalar da mevcuttur [27-29]. Kömür madenlerinde radon ölçümleri üzerine odaklanan çalışmamızda, dünyada günümüze dek yapılmış araştırmaların önemli bir kısmıyla birlikte ülkemizdeki ölçümlerin tamamı incelenerek derlenmiş ve atmosferik radon düzeyi için elde edilen sonuçlar tartışılarak değerlendirilmiştir. 


\section{RADON ÖLÇÜMLERİ}

Kapalı bir ortam atmosferindeki radon konsantrasyonunun ölçülmesi, ${ }^{222} \mathrm{Rn}$ 'nin doğal bozunma süreciyle ortaya çıkan $\alpha$-parçacıklarının (belirli bir hacim için) sayılması prensibine dayanmaktadır. Radon gazının varlığı ve miktarı, özel olarak geliştirilmiş cihazlar kullanılarak ortam havasından numune alma yoluyla veya yerinde ölçümlerle belirlenmektedir. Radon ölçümleri çalışmanın amacına göre; anlık olarak yapılabilir veya belirli bir dönemi kapsayan kümülatif ölçümler (kısa veya uzun-dönem ölçümler) şeklinde gerçekleştirilebilir. Maden ocaklarındaki genel durumun anlaşılabilmesi için mevsimsel uzun-dönem ölçümler yapmak daha uygundur. Kesintisiz veya belirli aralıklarla yerinde alınan ölçümler, uygun dedektörlerin ölçüm noktalarına yerleştirilerek belirli bir süre boyunca burada bırakılması ve daha sonra analiz işlemlerinin ardından sonuçların belirlenmesi aşamalarını içerir [5].

\section{A. Dünyada Genelinde Kömür Madenlerinde Radon Ölçümleri}

Bu bölümde, dünya genelindeki kömür madenlerinde farklı ölçüm teknikleri kullanılarak gerçekleştirilmiş radon ölçümlerinden bazıları tarihsel süreç dikkate alınarak sunulmakta ve ulaşılan sonuçlar toplu olarak Tablo 3 ile özetlenmektedir.

İngiltere'deki 12 kömür madeni için çalışma seviyesi (WL) değerlerinin belirlenmesi amacıyla yapılan bir araştırma kapsamında, radon konsantrasyonları ölçülmüş maksimum radon konsantrasyonunun $518 \mathrm{~Bq} / \mathrm{m}^{3}$ ve ortalama radon konsantrasyonunun ise $74 \mathrm{~Bq} / \mathrm{m}^{3}$ olduğu bildirilmiştir [30]. Yugoslavya'nın Slovenya şehrinde bulunan 6 kömür madeninde Ekim 1985 ile Haziran 1986 tarihleri arasında, sintilasyon hücresi yöntemiyle yapılan radon ölçümlerini içeren diğer bir çalışmada en yüksek radon kon- santrasyonu $655 \mathrm{~Bq} / \mathrm{m} 3$ olarak ve en düşük düzey ise 30 $\mathrm{Bq} / \mathrm{m} 3$ olarak kayıt edilmiştir [31].

Hindistan Godavarikhani'de eğimli 7 kömür madeni için atmosferik radon ölçümleri LR-115 tipi katıhal nükleer iz dedektörleri kullanılarak ölçülmüştür. Bu çalışmada, Mart 1995 ile Şubat 1996 tarihleri arasında incelenen 2 madende mevsimsel radon ölçümleri gerçekleştirilmiş, diğer 5 madende ise sadece kış dönemi ölçümleri (Aralık 1995-Şubat 1996) yapılmıştır. Yüksek radon seviyelerine; aktif madencilik operasyonlarının yapıldığı alanlarla birlikte hava dönüş galerilerinde ve madencilik faaliyetlerinin bulunmadığı bir bölgede rastlanmıştır. Çalışmada, mevsimsel ölçümlerin yapıldığı iki kömür madeni için ortalama radon konsantrasyonu $144 \pm 61 \mathrm{~Bq} / \mathrm{m}^{3}$ ve çalışma seviyesi

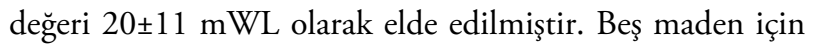
ön görülen ortalama radon seviyesi $315 \pm 71 \mathrm{~Bq} / \mathrm{m} 3$ ve WL

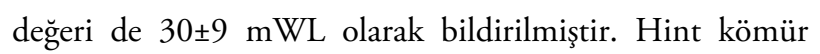
ocaklarında yapılan bu çalışma ile daha önce İngiliz kömür madenlerinde yapılan çalışmanın sonuçları [30] karşılaştırıldığında, benzer radon konsantrasyonlarının ölçüldüğü öne sürülmüştür [32]. Bu çalışmada ayrıca radon düzeyinin ocak derinliğine bağlı değişimi de incelenmiş, Schery ve arkadaşlarının 1984 yılında yaptıkları çalışmadaki yeryüzü seviyesinden derinlere inildikçe radon düzeyinin artmasına [33] benzer bir durum gözlemlenmek istenmiş, fakat radon düzeyi ile derinlik arasında anlamlı bir ilişki kurulamamıştır. Araştırmacılar toprağın porozitesi, sıcaklık, nem, havalandırma oranı ve diğer fiziksel parametrelerin, tek başına derinlik parametresinden daha baskın bir rol oynayabileceğini ileri sürmüşlerdir [32].

Başka bir çalışmada Pakistan'ın Baluchistan şehrindeki 6 kömür madeninde radon konsantrasyonları, CN-85 katı hal nükleer iz dedektörlerinin kullanıldığı kutu tipi dozimetrelerle ölçülmüştür. Her bir madenden 6 ölçüm alınmıştır. 36 ölçümün 121 ile $408 \mathrm{~Bq} / \mathrm{m}^{3}$ arasında değiştiği 


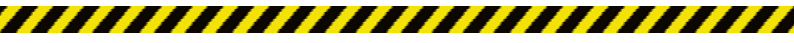

bildirilmiştir. Madenlerdeki ortalama radon düzeylerinin ise 143 ile $261 \mathrm{~Bq} / \mathrm{m}^{3}$ aralığında olduğu gösterilmiştir. Bu çalışmada da maden işçilerinin maruz kalacakları etkin dozlar (Godavarikhani çalışmasında [32] olduğu gibi), denge faktörü 0,5 alınarak hesaplanmış ve yıllık etkin dozun $2,19 \pm 0,5 \mathrm{mSv}$ olduğu $(1,38-4,67 \mathrm{mSv})$ tespit edilmiştir [9]. Pakistan'daki bu çalışma için dozimetreler, madenlerde 30 günü aşan bir süre buyunca radona maruz bırakılmıştır. Baluchistan kömür madenlerindeki maksimum radon düzeyinin Almanya'daki kömür madenlerinde 1976 yılına kadar gözlemlenen maksimum ölçümlerle (400 Bq/ m3) karşılaştırılabilir olduğu ve Birleşik Krallık’taki kömür madenleri için 1968 yılında rapor edilen maksimum değerden $\left(-500 \mathrm{~Bq} / \mathrm{m}^{3}\right)$ daha düşük olduğu bildirilmiştir. Bilindiği gibi, kömür madeni havzalarının ana litalojisi, jurasik çağın kireç taşları, killi kaya ve çakıl formlarıdır [9]. Pakistan'daki bu formasyondaki kayaçların yüksek düzeyde uranyum içeriği barındırmadığı için yüksek düzeyde bir radon salınımı beklenmediği belirtilmiştir. Pakistan'daki Baluchistan kömür ocaklarında tespit edilen radon yoğunluklarının başlıca nedeninin iyi havalandırılmayan kapalı ortam olduğu vurgulanmıştır. Bu çalışma sonunda, Baluchistan kömür madenlerinde çalışan madencilerin radon nedeniyle aldıkları yıllık etkin doz eşdeğerlerinin o dönem için geçerli olan ICRP'nin 65 nolu raporundaki müdahale limitinden [34] daha düşük olduğu bildirilmiştir [9].

Veiga ve arkadaşları 2004'te yayımladıkları çalışmalarında, Brezilyanın güneyinde bulunan ve yüksek radon konsantrasyonuna sahip olduğu bilinen bir kömür madenine ait sahalardaki radyolojik durumu, Aralık 1999 (saha 1'deki 1. ölçümler), Mayıs 2000 (saha 1'deki 2. ölçümler) ve Nisan 2003 (saha 7’deki 3. ölçümler) tarihlerinde yaptıkları ölçümlerle belirlemişler ve işçilerin maruz kalacakları yıllık dozları hesaplamışlardır. Araştırmacılar o tarihte, Brezilya'daki aktif olan 33 madenden 8 tanesinin kömür madeni olduğunu ve inceledikleri kömür havzasının bir uranyum maden yatağının yanında konumlandığını bildirmişlerdir. Bu nedenle yüksek radon konsantrasyonları gözlemlenmiş ve inceleme altındaki sahada çalışan işçilerin maruz kalacakları yıllık etkin doz ortalamasının dünya kömür madenlerindeki ortalamadan neredeyse 30 kat daha fazla olduğu bulunmuştur [35]. Her 3 ölçümde de işletmelerdeki atmosferik radon seviyeleri Alpha Guard (Gentron Instruments) taşınabilir radon monitörü kullanılarak belirlenmiş ve kişisel radon ölçümleri, işçilerin kasklarına konumlandırılan iz kazıma dozimetreleri ile ölçülmüştür. Ayrıca 1. ve 2. ölçümlerde, çalışma seviyesi değerleri doğrudan WLM-200 plus dedektörü kullanılarak tespit edilmiştir. Çalışma sonucunda, Alpha Guard ile yapılan anlık atmosferik radon seviyelerinin 0,78 ile $7,2 \mathrm{kBq} / \mathrm{m}^{3}$ aralığında gözlemlendiği ve kişisel radon konsantrasyonu ölçümlerinin $1650 \mathrm{~Bq} / \mathrm{m}^{3}$ lük bir ortalamaya $\left(170-6100 \mathrm{~Bq} / \mathrm{m}^{3}\right)$ sahip olduğu bulunmuştur. Bireysel ölçümlerin \%92'sinin $500 \mathrm{~Bq} / \mathrm{m}^{3}$ değerinden büyük olduğu ve \%40'ının ise ICRP'nin o tarihteki $1500 \mathrm{~Bq} / \mathrm{m}^{3}$ 'lük üst sınır değerini [34] aştığı bildirilmiştir [35]. Brezilya kömür madeninde çalışan işçiler için (bireysel radon ölçümleri dikkate alınarak) yıllık çalışma düzeyi ortalamasının 2,1 WLM ve yıllık etkin doz eşdeğeri ortalamasının 10,7 mSv/yıl olduğu rapor edilmiştir [35].

Diğer bir çalışmada, İran'daki yedi kömür madeninde (ve üç metal madeninde) ${ }^{222} \mathrm{Rn}$ konsantrasyon seviyeleri, aktif karbon ve sintilasyon hücresi tekniğine dayalı iki aktif yöntem kullanılarak ölçülmüştür. Eshkeli kömür madeninde 12 radon ölçümü yapılmış diğer altı kömür madeninde ise 10 'ar ölçüm alınmıştır. Sonuçlar, kömür madenlerinin üçünün $200 \mathrm{~Bq} / \mathrm{m}^{3}$ ten daha düşük bir radon düzeyine sahip olduğunu ve en yüksek ortalamanın Pabdana kömür madeninde gözlemlendiğini göstermiştir $\left(520 \pm 68 \mathrm{~Bq} / \mathrm{m}^{3}\right)$. Araştırmacılar genel olarak, çalıştıkları kömür madenlerin- 
deki radon konsantrasyon düzeylerini Tayvan, Slovenya ve Birleşik Krallık'taki ölçümler ile karşılaştırmışlar, Tayvan kömür madenlerindeki $88,5 \mathrm{~Bq} / \mathrm{m}^{3}$ lük ortalamadan [36] daha yüksek ve Slovenya $\left(<500 \mathrm{~Bq} / \mathrm{m}^{3}\right)$ [31] ile Birleşik Krallık'ta kömür madenlerinde gözlemlenen düzeyden $\left(<620 \mathrm{~Bq} / \mathrm{m}^{3}\right)$ [37] daha düşük bir seviyede, yaklaşık 320 $\mathrm{Bq} / \mathrm{m}^{3}$ lük bir ortalama tespit ettiklerini bildirmişlerdir [38]. Buna ek olarak, kömür madenlerindeki işçilerin maruz kalacakları yıllık etkin doz eşdeğerlerinin ICRP tarafından tavsiye edilen limit değerleri aşmadığı bulunmuştur. Diğer taraftan yedi kömür madeni için hesaplanan yıllık doz eşdeğerinin $(-2 \mathrm{mSv})$, UNSCEAR tarafindan kömür madenleri için bildirilen $0,7 \mathrm{mSv}$ 'lik ortalama değerden daha büyük olduğu rapor edilmiştir [38].

Veiga ve arkadaşları, 2006 yılında Brezilya'daki maden ocaklarında radona maruz kalan işçilerin ölüm oranlarını geçmişi de kapsayacak biçimde (1942 yllından başlatarak) çalışmışlardır. 2004 yılında çalışılan kömür madenine ait verileri [35] baz alarak tahmini yıllık radon ürünlerine maruz kalma düzeyinin 0,2-7,2 WLM arasında değiştiğini kabul etmişlerdir. Yıllık ortalama radon ürünlerine maruz kalma düzeyi 2,1 WLM olarak alınmıştır. Buradan hareketle, hem yeraltı hem de yerüstü çalışanları için istatistiksel olarak standart ölüm oranı (SMR) analizi yapılmıştır. $\mathrm{Bu}$ analizlerin sonucunda yerüstü ve yeraltı işletmeleri için istatistiksel açıdan önemli ölüm oranları gözlenmiştir. Yeraltı madencileri için gözlenen artan akciğer kanseri mortalitesinin, radon maruziyeti ile ilişkili olduğu tespit edilmiş, ancak maruz kalma süresine bağlı ilişki ortaya konulamamıştır [39]. 2018 yılında Brezilya yeraltı madenleri için yayımlanan diğer bir çalışmada, Brezilya’da 40 maden için yapılan ölçümler incelenmiş ve daha önce kömür madenleri için yapılan radon ölçümleri de $[35,39]$ bu çalışma içerisinde yeniden değerlendirilmiştir [40].

2007 yılında yayımlanan bir çalışmada, Çin'deki yeraltı kömür madenlerinde çalışanların sayısı ve bu madencilerin maruz kaldıkları yıllık dozun tahmin edilmesi üzerine bir yöntem sunulmuştur [41]. Maruz kalınan mesleki radyasyonun değerlendirilmesinde, yıllık üretim ve havalandırma durumu dikkate alınarak kömür madenleri üç kategoride incelenmiştir. Bunlardan birincisi, yüksek üretim yapan ve doğrudan merkezi hükümet tarafından kontrol edilen iyi havalandırma koşullarına sahip ana kömür madenleridir (NKCM). İkincisi, nispeten yüksek üretimli ve doğrudan yerel yönetimler tarafından kontrol edilen kısmen iyi havalandırma koşullarına sahip, yerel kömür madenlerini (SLCM) kapsamaktadır. Üçüncüsü, düşük üretimli ve havalandırmanın yetersiz olduğu, ilçe ve özel mülkiyetli kömür madenleridir (TPCM). Radon konsantrasyonlarının belirlenmesinde, kümülatif ölçüm tekniği (belirli bir ölçüm periyodu içerisinde radon ölçümleri için ortalama düzeyin tespit edildiği yöntem) ve anlık ölçüm tekniği kullanılmıştır. Kümülatif ölçümlerde, Çin'de üretilen KF606 dedektörleriyle birlikte Çin menşeili termolüminesans dozimetreleri ve Japonya'da üretilen CR-39 nükleer iz dedektörlerinden yararlanılmıştır. Anlık radon konsantrasyonu ölçümlerinde ise sürekli ölçüm yapabilen elektronik radon monitörü RAD7 kullanılmıştır (218 noktada anlık ölçüm yapılmışıır). Kümülatif ölçümlerde kullanılan detektörlerden \% 67'si geri toplanabilmiştir (1415 detektör dağıtılmış ve 943'ü geri toplanabilmiştir). Çalışma kapsamında 50000 madencinin çalıştığı 50 kömür madeni incelenmiş ve Çin'deki kömür madenleri için daha önceki çalışmalardan elde edilen sonuçlar da kullanılarak toplamda 84 kömür madeni değerlendirilmiştir. Radon düzeyleri, NKCM madenleri için (30 maden) $18-202 \mathrm{~Bq} / \mathrm{m}^{3}$ aralığında ve ortalama $77 \mathrm{~Bq} / \mathrm{m}^{3}$ olarak, SLCM madenleri için (27 maden) 22 $-1963 \mathrm{~Bq} / \mathrm{m}^{3}$ aralığında ve ortalama $189 \mathrm{~Bq} / \mathrm{m}^{3}$ olarak, TPCM madenleri için (19 maden) 14-3115 Bq/ $\mathrm{m}^{3}$ aralığında ve ortalama $536 \mathrm{~Bq} / \mathrm{m}^{3}$ olarak ve kemik kömürü 


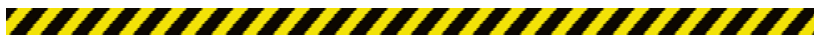

(bone-coal) işletmeleri için (8 maden) $136-23976 \mathrm{~Bq} / \mathrm{m}^{3}$ aralığında ve ortalama $5997 \mathrm{~Bq} / \mathrm{m}^{3}$ olarak tespit edilmiştir [41].

Vietnam Nui Beo bölgesinde, kömür madenciliği yapılan sahadaki meskenler için bina içi ve bina dışı radon konsantrasyonlarının incelendiği bir çalışmada, 37 mekanda LR-115 pasif nükleer iz dedektörleri kullanılarak 2010 yılının Haziran ve Temmuz ayları arasında atmosferik radon ölçümleri gerçekleştirilmiştir. Bina içi radon düzeylerinin $145 \mathrm{~Bq} / \mathrm{m}^{3}$ değerine kadar ulaştığı ve ortalamanın $46 \pm 26 \mathrm{~Bq} / \mathrm{m}^{3}$ olduğu bulunmuştur. Bina dişı radon ortalaması ise $43 \pm 19 \mathrm{~Bq} / \mathrm{m}^{3}(\mathrm{n}=10)$ olarak tespit edilmiştir. Bir kıyı kasabası olan bu bölgede limana yakın bir kömür deposunda yapılan 3 ölçüm sonucunda ortalama radon düzeyinin $67 \pm 4 \mathrm{~Bq} / \mathrm{m}^{3}$ olduğu görülmüş̧ür. Yapılan tüm çalışmalarla birlikte, kömür madenciliği sahası dışındaki yakın bir yerleşim birimindeki (Ha Noi şehri) bina içi radon düzeyi $30 \mathrm{~Bq} / \mathrm{m}^{3}$ olarak belirlenmiştir. Madencilik yapılan bölgedeki bina içi radon düzeyinin yaklaşık 1,7 kat daha fazla olduğu bulunmuştur. Bu fazlalığın kömür üretiminden kaynaklanabileceği (kömür deposundaki yüksek düzey göz önüne alınarak) iddia edilmiştir. Kömürcülük faaliyetlerinin yapıldığg bu bölgede, kömürdeki radonun atmosfere karıştığı öne sürülmüş, bina içi ve bina dışı radon düzeylerinin bu yüzden birbiri ile oldukça benzer olduğu bildirilmiştir [42]. Bu çalışmadaki radon ölçümleri SPSS programı ile istatistiksel olarak analiz edilmiştir. Bina içi radon ölçümlerinin normal dağılıma sahip olduğu rapor edilmiştir. Fakat pek çok araştırmacı tarafından da gösterildiği gibi bina içi radon konsantrasyonu ölçümleri genellikle lognormal dağılım sergilerler [43]. Bu çalışmanın sonuçları, bölgede yüksek bir ${ }^{222} \mathrm{Rn}$ düzeyinin olmadığını dolayısı ile kömür madenciliği faaliyetlerinin radona maruz kalma açısından önemli bir halk sağlığı riski taşımadığını, sadece bina içi ve bina dışı radon düzeylerinin neredeyse aynı sevi- yeye gelmesine neden olduğunu göstermektedir [42].

Portola ve arkadaşları, Rusya, Kuzbass bölgesi kömür madenlerinde, gama spekrometrik ölçümler ile radyum aktivitelerini belirlemişlerdir. Tespit ettikleri radyum aktivitelerinden yola çıkarak maden atmosferindeki radon hacim aktivitelerini belirlemişlerdir. Çalışma, Kuzbass bölgesinde aktif olarak işletilen 10 maden yatağındaki 25 ölçüm noktasında ve yine bu bölgede madencilik faaliyeti yapılmayan 25 galeride gerçekleştirilmiştir. Faal olan kömür madenleri için radon hacim aktiviteleri $15-288 \mathrm{~Bq} / \mathrm{kg}$ arasında değişirken madencilik dışında kalmış (uzun bir süreden beri izole edilmiş) galerilerin atmosferindeki radon aktivitelerinin 74-5636 Bq/kg aralığında (25 ölçümün 9 tanesi $1000 \mathrm{~Bq} / \mathrm{kg}$ değerinden yüksektir) gözlemlendiği bildirilmiştir. Maden atmosferindeki radon konsantrasyonunu etkileyen en önemli faktörlerden birinin ventilasyon miktarı olduğu sonucuna varmışlardır [44].

Trzeciakiewicz ve Parkitny 2015 yılında yayımladıkları çalışmalarında, Polonya'da "Kömür Madeni” olarak bilinen yeraltı turist rotasında radon konsantrasyonlarını aktif ve pasif ölçüm teknikleri kullanarak incelemişlerdir. Pasif ölçümler 2004-2007 yılları arasında 4 ölçüm noktasında ve 2011 yılında 21 ölçüm noktasında, LR115 katı-hal nükleer iz dedektörleri kullanılarak gerçekleştirilmiş ve dedektörler her mevsim başlangıcında yenisiyle değiştirilmiştir. Böylelikle radon yoğunluğunun mevsimsel değişimleri incelenmiş, en yüksek radon düzeylerinin yaz mevsimlerinde ve en düşük radon seviyelerinin ise kış mevsimlerinde gözlemlendiği bildirilmiştir. Mevsimsel radon değişimindeki ana diş etkenin hava sıcaklığındaki değişimden kaynaklandığı öne sürülmüştür. Mevsimsel atmosferik basınçtaki (hava basıncındaki) değişim ile radon düzeyi arasında anlamlı bir ilişki kurulamamıştır. Bu tesisteki ortalama radon düzeyi 799 $\mathrm{Bq} / \mathrm{m}^{3}$ olarak bildirilmiş ve bu değerin Polonya'daki kömür madenlerinde gözlemlenen radon konsantrasyonları 
ile tutarlı olduğu belirtilmiştir [45]. Radon konsantrasyonundaki günlük değişimler Mayıs 2012 de RadStar RS-230 cihazı kullanılarak kayıt edilmiştir. Radon seviyelerinin genel olarak, sabah 8-9 saatleri ile akşam 7-8 saatleri arasında en yüksek değerlere ulaştığı ve gece saatleride de en dü- şük seviyelere indiği belirlenmiştir. Radon düzeylerindeki saatlik değişimlerin hava sıcaklığındaki saatlik değişimler ile ilişkili olduğu sonucuna varılmıştır. Basınç, hava hızı yada yağış gibi diğer meteorolojik parametreler ile saatlik radon değişimleri arasında bir korelasyon bulunamamıştır.

Tablo 3: Dünyada kömür madenlerinde yapılmış bazı radon ölçümleri

\begin{tabular}{|c|c|c|c|c|c|}
\hline Ülke & Metot & Maden sayısı & $\begin{array}{c}\mathrm{C}_{\mathrm{Rn}} \\
\left(\mathrm{Bq} / \mathrm{m}^{3}\right)\end{array}$ & YEDE (mSv/yıl) & Kaynak \\
\hline Birleşik Krallık & $\begin{array}{l}\text { Alfa aktivitesi tayi- } \\
\text { ni }\end{array}$ & 12 & $\begin{array}{c}74 \\
(22-518)\end{array}$ & & [30] \\
\hline Birleşik Krallık & Lucas hücresi & 5 & $\begin{array}{c}574^{*} \\
(151-1244)^{*}\end{array}$ & & [37] \\
\hline Tayvan & CN filmleri & 2 & $88,5 \pm 9,5$ & & [36] \\
\hline $\begin{array}{l}\text { Hindistan } \\
\text { (Godavarikhani) }\end{array}$ & LR-115 & 2 & $\begin{array}{c}145 \\
(46-354)\end{array}$ & & $\begin{array}{c}\text { [32] } \\
\text { (Ö.Y:1995-1996) }\end{array}$ \\
\hline $\begin{array}{l}\text { Yugoslavya } \\
\text { (Slovenya) }\end{array}$ & Sintilasyon hücresi & 6 & $(30-655)$ & & [31] \\
\hline İran & $\begin{array}{l}\text { Aktif karbon, } \\
\text { Sintilasyon hücresi }\end{array}$ & 7 & $\begin{array}{c}320 \\
(146-520)\end{array}$ & 3 & [38] \\
\hline \multirow{3}{*}{ Çin } & & $\begin{array}{c}30 \\
\text { (NKCM) }\end{array}$ & $\begin{array}{c}77 \\
(18-202)\end{array}$ & \multirow{3}{*}{10} & \multirow{3}{*}{ [41] } \\
\hline & $\begin{array}{l}\text { K606, } \\
\text { RAD7, } \\
\text { CR39 }\end{array}$ & $\begin{array}{c}27 \\
\text { (SLCM) } \\
19 \\
\text { (TPCM) }\end{array}$ & $\begin{array}{c}189 \\
(22-1963) \\
536 \\
(14-3115)\end{array}$ & & \\
\hline & & $\begin{array}{c}8 \\
\text { (Kemik kömürü) }\end{array}$ & $\begin{array}{c}5997 \\
(136-23976)\end{array}$ & & \\
\hline Polonya & & 71 & $\begin{array}{c}740 \\
(0-7000)\end{array}$ & & [28] \\
\hline Polonya & $\begin{array}{l}\text { RS-230, } \\
\text { LR-115 }\end{array}$ & 1 & $\begin{array}{c}799 \\
(94-1301)\end{array}$ & $3,5-5,8$ & $\begin{array}{c}\text { [45] } \\
(\text { Ö.Y:2011) }\end{array}$ \\
\hline Çin & CR-39 & 1 & (65-189) & $0,8-1,49$ & $\begin{array}{c}\text { [46] } \\
\text { (Ö.Y:2012-2013) }\end{array}$ \\
\hline Brezilya & Alpha Guard & 1 & $\begin{array}{c}1650 * * \\
(170-6100)\end{array}$ & 10,7 & $\begin{array}{c}\text { [35] } \\
\text { (Ö.Y:1999-2000) }\end{array}$ \\
\hline $\begin{array}{l}\text { Pakistan } \\
\text { (Baluchistan) }\end{array}$ & $\mathrm{CN}-85$ & 6 & $\begin{array}{c}192 \\
(121-408)\end{array}$ & $1,38-4,67$ & [9] \\
\hline
\end{tabular}

Birleşik Krallık için verilen radon seviyeleri, 5 maden için elde edilen maksimum değerlerin ortalamasını ve maksimum değerlerin değişimini göstermektedir.

**Bu veriler, Brezilya kömür madenlerindeki bireysel radon konsantrasyonu ölçümlerine aittir. Ö.Y: Ölçüm yılını göstermektedir. 
Araştırmacılar yaptıkları radon ölçümleri sonucunda, mekanik havalandırma sistemine sahip olmayan yeralı işletmeleri için radon düzeylerindeki değişimin hava hareketlerini takip etmesi bakımından mükemmel bir belirleyici olabileceğini öne sürmüşlerdir. Bu araştırmada ayrıca, işletmede çalışanların radon nedeni ile alacakları dozların 3,5 ile $5,8 \mathrm{mSv} / \mathrm{yll}$ arasında değiştiği saptanmış ve radyasyon düzeylerinin sürekli olarak izlenmesi tavsiye edilmiştir [45].

Çin’de 3 farklı maden için yapılan bir çalışmada, 20122013 tarihleri arasında birbirini takip eden 4 mevsim boyunca CR-39 dedektörleriyle eş zamanlı saha ölçümleri ve 120 maden çalışanı üzerinde de aynı tip pasif monitörler kullanılarak kişisel ölçümler gerçekleştirilmiştir [46]. Saha ölçümlerine göre atmosferik radon düzeylerinin; kömür madeni için $65 \mathrm{~Bq} / \mathrm{m}^{3}$ ile $189 \mathrm{~Bq} / \mathrm{m}^{3}$ arasında, demir madeni için $183 \mathrm{~Bq} / \mathrm{m}^{3}$ ile $826 \mathrm{~Bq} / \mathrm{m}^{3}$ arasında ve bakır madeni için $452 \mathrm{~Bq} / \mathrm{m}^{3}$ ile $1930 \mathrm{~Bq} / \mathrm{m}^{3}$ değerleri arasında değiştiği tespit edilmiştir. En yüksek radon konsantrasyonları bakır madeninde, en düşük radon konsantrasyonları ise kömür madeninde gözlemlenmiştir. Patlayıcı ve diğer zararlı gazların maden atmosferinden uzaklaştırılabilmesi için kömür madenlerindeki ventilasyon düzeyinin daha yüksek oluşuna vurgu yapılmış ve bu durumun kömür madenindeki radon ölçümlerinin düşük çıkmasının nedeni olabileceği belirtilmiştir [46]. Ek olarak, bu madenlerdeki kişisel monitörleme ve saha ölçümlerine ait veriler kullanılarak radon nedeniyle maruz kalınacak yıllık dozlar hesaplanmıştır. Kişisel monitörleme verilerine göre yıllık etkin doz düzeyleri bakır, demir ve kömür madenleri için sırasıyla 6,61 $\mathrm{mSv}, 2,70 \mathrm{mSv}$ ve $0,80 \mathrm{mSv}$ olarak bulunmuştur. Saha ölçümlerinden elde edilen radon konsantrasyonları dikkate alındığında yıllık dozların; bakır madeni için 10,76 $\mathrm{mSv}$, demir madeni için 4,48 $\mathrm{mSv}$ ve kömür madeni için 1,49 mSv olarak hesaplandığı bildirilmiştir. Bu sonuçlardan hareketle, sadece saha ölçümleri ile (çevresel monitör- leme ile) yapılacak yıllık doz tahminlerinin gerçek durumu olduğundan daha büyük gösterebileceği vurgulanmıştır [46].

Bu bölümde incelenen kömür madenlerindeki atmosferik radon ölçümlerine ait bulgular, incelenen kömür madeni sayısı ve kullanılan radon ölçüm yöntemleriyle birlikte topluca Tablo 3 ile özetlenmektedir. Araştırmacıların madenler için bulduğu ortalama radon konsantrasyonu (CRn) değerleri $\mathrm{Bq} / \mathrm{m}^{3}$ cinsinden verilmekte, bildirilen minimum ve maksimum ölçüm değerleri parantez içerisinde gösterilmektedir. Yıllık etkin doz eşdeğerlerinin (YEDE'nin) hesaplandığı çalışmalar için maruz kalınacak yıllık dozlar, $\mathrm{mSv} / \mathrm{yıl}$ cinsinden rapor edildiği şekliyle sunulmaktadır.

\section{B. Ülkemizdeki Kömür Madenlerinde Radon Ölçümleri}

Türkiye'de madenlerle ilgili yapılan ilk radon gazı ölçümleri, Ege Üniversitesi Nükleer Enerji Enstitüsü tarafından yeraltı maden ocakları çalışanlarının maruz kaldığı radyasyon dozlarının belirlenmesi amacıyla Ege Bölgesi'nde, Ekim 1994 ile Ekim 1995 tarihleri arasında, bor, krom ve kömür (linyit) madenlerinde gerçekleştirilmiştir. Çalışma kapsamında, Lucas hücresi ve CR-39 nükleer iz dedektörleri kullanılmıştır. Ocaklardaki radon konsantrasyonlarının, bor için 29-197 Bq/m³, krom için 10-35 Bq/ $\mathrm{m}^{3}$ ve linyit madenleri için $26-166 \mathrm{~Bq} / \mathrm{m}^{3}$ arasında değiştiği bulunmuştur [47]. Ölçümlerin yapıldığı dönemlerde, ocakların yeterli hava değişimini sağlayacak havalandırma sistemlerine sahip oldukları bildirilmiştir [47, 48].

Türkiye'deki taşkömürü üretimi sadece, Zonguldak ili ve çevresindeki bitümlü kömür havzasında (Karbonifer Penceresi'nde), TTK (Türkiye Taşkömürü Kurumu) işletmelerinde gerçekleştirilmektedir. Zonguldak bitümlü kömür havzasında bulunan maden işletmelerindeki radon ölçümlerinde, genelde pasif nükleer iz dedektörleri kulla- 
nılmıştır. Ocak 2002 ile Mart 2002 tarihleri arasında, Koz-

lu, Karadon ve Üzülmez işletmeleri için yapılan ölçümlerde ortalama radon konsantrasyonları, sırasıyla $656 \mathrm{~Bq} / \mathrm{m}^{3}$, $705 \mathrm{~Bq} / \mathrm{m}^{3}$ ve $672 \mathrm{~Bq} / \mathrm{m}^{3}$ olarak belirlenmiştir [49-51]. Daha sonraki bir çalışmada, Amasra taşkömürü ocağındaki atmosferik radon düzeyleri ölçülmüş ve ortalama düzeyin $117 \mathrm{~Bq} / \mathrm{m}^{3}$ olduğu bildirilmiştir [52]. Armutçuk işletmesine ait yeraltı kömür madenindeki radon seviyelerinin araştırıldığı başka bir çalışmada ise ölçümler iki mevsim boyunca tekrarlanmıştır. Ortalama radon konsantrasyonlarının bahar mevsiminde $238 \mathrm{~Bq} / \mathrm{m}^{3}$ ve yaz mevsiminde 161 $\mathrm{Bq} / \mathrm{m}^{3}$ olduğu tespit edilmiştir [53]. Bu çalışmalardan elde edilen tüm ortalamalar, TAEK'in iş yerleri için belirlediği sınır değer olan $1000 \mathrm{~Bq} / \mathrm{m}^{3}$ değerlerinden düşüktür. $\mathrm{Bu}$ çalışmalarda, müesseselerde çalışanlar için etkin doz eşdeğerleri de hesaplanmıştır. 2017 yılında, TTK’ya bağlı 5 madende daha önceden yapılan radon ölçümleri (Kozlu, Karadon ve Üzülmez işletmeleri için yapılan çalışma [51], Amasra işletmesindeki ölçümler [52] ve Armutçuk taşkömürü ocağındaki çalışma [53]) Baldık ve Aytekin tarafından bir araya getirilerek maden çalışanlarının radon nedeniyle maruz kalacakları doz değerleri ve yaşam boyu ölüm riskleri karşılaştırılmıştır [54]. Bu çalışmada, Kozlu işletmesi için saptanan en yüksek yıllık etkin doz eşdeğeri dışındaki doz değerlerinin ICRP'nin $10 \mathrm{mSv} / \mathrm{yll}$ 'lık müdahale limitinin [34] altında olduğu bildirilmiştir. Kozlu, Karadon ve Üzülmez ocaklarında 2002 yılında yapılan ölçümlere ait bulguların [51], 2005 yılından sonra Amasra [52] ve Armutçuk işletmelerinden [53] elde edilen sonuçlara göre daha yüksek olması, havalandırmanın yetersizliğiyle ilişkilendirilmiş ve Fişne ve arkadaşlarının dedektörler üzerindeki alfa izlerini manuel olarak okumalarının da sonuçlar üzerinde etkili olabileceği bildirilmiştir. Daha sağlıklı bir değerlendirme için Kozlu, Karadon ve Üzülmez işletmeleri için ölçümlerin tekrarlanması tavsiye edilmiştir [54]. Kar- bonifer Penceresi için gerçekleştirilen diğer bir çalışmada, Zonguldak Bülent Ecevit Üniversitesi'nden (eski Zonguldak Karaelmas Üniversitesi'nden) bir araştırma grubu, TTK’ya bağlı 5 işletmenin hava dönüş galerilerindeki 66 ölçüm noktasında, Aralık 2007 ile Kasım 2008 tarihleri arasında eşzamanlı olarak mevsimsel atmosferik radon konsantrasyonlarını ölçmüşlerdir. Hava dönüş galerilerinin seçilmesinin nedeni, farklı kotlarda bulunan tüm ocaklara ait havanın bu galerilerde bir araya gelmesinden dolayı yeraltı kömür ocaklarındaki genel radon düzeyi hakkında bir fikir sahibi olunabileceği düşüncesidir. Her ölçüm noktasına, biri hava akımına dik diğeri ise paralel olarak konumlandırılan uzun-dönem CR-39 pasif nükleer iz dedektörleri yerleştirilmiştir. Dedektörlerin analizleri, TAEK'e bağlı Sarayköy Nükleer Eğitim ve Araştırma Merkezi'nin Sağlık Fiziği biriminde yapılmıştır. Ölçümlerin işletme bazında yıllık radon düzeyi ortalamaları ele alındığında, hava akımına dik olarak yerleştirilen dedektörlerin yatay konumdakilere göre biraz daha fazla radon yoğunluğu kaydettiği söylenebilir [55]. Ancak bu 5 işletmeden elde edilen ölçümler istatistiksel olarak incelendiğinde, muhtemelen analiz aşamasındaki teknik bir hatadan dolayı anormal biçimde düşük çıkan güz mevsimi verilerinin değerlendirmeden çıkarılması gerektiği ve dedektör pozisyonlarının ölçülen radon yoğunluğu üzerindeki etkisinin istatistiksel olarak önemli olmadığı görülmüştür [56]. Bu istatistiksel çalışmada, kış, bahar ve yaz mevsimleri için ölçüm noktalarındaki ortalama radon düzeyleri veri olarak kabul edilmiş ve genel olarak, radon konsantrasyonlarının hem mevsime hem de işletme konumuna bağlı değişiminin istatistiksel olarak önemli olduğu gösterilmiştir $(\mathrm{p}<0,01)$ [56]. Armutçuk, Kozlu, Karadon, Amasra ve Üzülmez işletmeleri için Akgönül tarafından saptanan ortalama radon düzeyleri [56]; 2005 sonrası ölçüm yapan araştırmacıların Amasra [52] ve Armutçuk [53] ocakları için bildirdikleri sonuçlarla 
Tablo 4: Türkiye'deki kömür madenlerinde yapılmış radon ölçümleri

\begin{tabular}{|c|c|c|c|c|c|c|c|c|c|}
\hline \multirow[t]{2}{*}{ Maden } & \multirow[t]{2}{*}{ Metot } & \multirow[t]{2}{*}{ D.S. } & \multirow[t]{2}{*}{ Ö.S. } & \multicolumn{3}{|c|}{$\begin{array}{c}C_{R n} \\
\left(B q / m^{3}\right)\end{array}$} & \multirow[t]{2}{*}{ YEDE (mSv/yıl) } & \multirow{2}{*}{$\begin{array}{c}\text { WLM } \\
\text { (WLM/yıl) }\end{array}$} & \multirow[t]{2}{*}{ Kaynak } \\
\hline & & & & Min & Maks & Ort. & & & \\
\hline $\begin{array}{l}\text { Zonguldak } \\
\text { (Kozlu) }\end{array}$ & \multirow{3}{*}{ CR-39 } & 34 & 42 & 359 & 1470 & 656 & 4,72 & 0,83 & \multirow{3}{*}{ [49-51] } \\
\hline $\begin{array}{l}\text { Zonguldak } \\
\text { (Karadon) }\end{array}$ & & 34 & 39 & 253 & 1213 & 705 & 5,08 & 0,90 & \\
\hline $\begin{array}{l}\text { Zonguldak } \\
\text { (Üzülmez) }\end{array}$ & & 16 & 39 & 428 & 1098 & 672 & 4,84 & 0,85 & \\
\hline \multirow{2}{*}{$\begin{array}{l}\text { Zonguldak } \\
\text { (Amasra) }\end{array}$} & \multirow{2}{*}{ CR-39 } & \multirow[t]{2}{*}{14} & \multirow[t]{2}{*}{40} & \multirow[t]{2}{*}{49} & \multirow[t]{2}{*}{223} & \multirow[t]{2}{*}{117,4} & 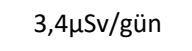 & & {$[52]$} \\
\hline & & & & & & & 0,85 & 0,15 & {$[54]$} \\
\hline \multirow[t]{2}{*}{$\begin{array}{l}\text { Zonguldak } \\
\text { (Armutçuk) }\end{array}$} & \multirow[t]{2}{*}{ CR-39 } & \multirow[t]{2}{*}{$20 \times 2$} & \multirow[t]{2}{*}{60} & $\begin{array}{l}B: 63 \\
Y: 37\end{array}$ & \multirow[t]{2}{*}{$\begin{array}{l}\text { B: } 706 \\
Y: 426\end{array}$} & $\begin{array}{l}B: 238 \\
Y: 161\end{array}$ & 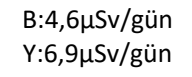 & & {$[53]$} \\
\hline & & & & & & 199,5 & 1,44 & 0,25 & [54] \\
\hline $\begin{array}{l}\text { Zonguldak } \\
\text { (Armutçuk) }\end{array}$ & \multirow{5}{*}{ CR-39 } & $24 \times 3$ & 42 & 21 & 178 & 91 & 0,57 & 0,12 & \multirow{5}{*}[56]{} \\
\hline $\begin{array}{l}\text { Zonguldak } \\
\text { (Kozlu) }\end{array}$ & & $44 \times 3$ & 42 & 16 & 421 & 81 & 0,39 & 0,10 & \\
\hline $\begin{array}{l}\text { Zonguldak } \\
\text { (Üzülmez) }\end{array}$ & & $16 \times 3$ & 42 & 26 & 465 & 114 & 0,72 & 0,14 & \\
\hline $\begin{array}{l}\text { Zonguldak } \\
\text { (Karadon) }\end{array}$ & & $38 \times 3$ & 42 & 25 & 478 & 101 & 0,64 & 0,13 & \\
\hline $\begin{array}{l}\text { Zonguldak } \\
\text { (Amasra) }\end{array}$ & & $10 \times 3$ & 42 & 10 & 502 & 125 & 0,79 & 0,16 & \\
\hline $\begin{array}{l}\text { Zonguldak } \\
\text { (Üzülmez) }\end{array}$ & \multirow{3}{*}{$\begin{array}{c}\text { SIVI } \\
\text { sintilasyon }\end{array}$} & 10 & 4 & $<15$ & 19 & $<19$ & & & \multirow{3}{*}{ [57] } \\
\hline $\begin{array}{l}\text { Zonguldak } \\
\text { (Kozlu) }\end{array}$ & & 3 & 4 & 37 & 78 & 53 & & & \\
\hline $\begin{array}{l}\text { Zonguldak } \\
\text { (Karadon) }\end{array}$ & & 1 & 4 & 22 & 22 & 22 & & & \\
\hline $\begin{array}{l}\text { Ege Bölgesi } \\
\text { (Maden 1) }\end{array}$ & \multirow{5}{*}{$\begin{array}{l}\text { Lucas hücresi } \\
\text { ve CR-39 }\end{array}$} & & 1 yıl & 51 & 96 & & & $0,21-0,67$ & \multirow{5}{*}{ [48] } \\
\hline $\begin{array}{l}\text { Ege Bölgesi } \\
\text { (Maden 2) }\end{array}$ & & & $1 \mathrm{yıl}$ & 42 & 185 & & & $0,13-0,86$ & \\
\hline $\begin{array}{l}\text { Ege Bölgesi } \\
\text { (Maden 3) }\end{array}$ & & & 1 yıl & 33 & 74 & & & $0,22-0,55$ & \\
\hline $\begin{array}{l}\text { Ege Bölgesi } \\
\text { (Maden 4) }\end{array}$ & & & 1 yıl & 31 & 156 & & & $0,20-0,95$ & \\
\hline $\begin{array}{l}\text { Ege Bölgesi } \\
\text { (Maden 5) }\end{array}$ & & & $1 \mathrm{yıl}$ & 74 & 96 & & & $0,49-0,62$ & \\
\hline $\begin{array}{l}\text { Kütahya } \\
\text { (Tunçbilek) }\end{array}$ & \multirow{3}{*}{ CR-39 } & 50 & $\sim 60$ & 50 & 272 & 172 & 1,23 & 0,25 & \\
\hline $\begin{array}{l}\text { Kütahya } \\
\text { (Ömerler) }\end{array}$ & & 50 & $\sim 60$ & 109 & 587 & 340 & 2,44 & 0,49 & [59] \\
\hline $\begin{array}{l}\text { Kütahya } \\
\text { (Eynez) }\end{array}$ & & 50 & $\sim 60$ & 75 & 442 & 205 & 1,47 & 0,29 & \\
\hline $\begin{array}{l}\text { Çorum } \\
\text { (Maden 1) }\end{array}$ & & 28 & $42-60$ & 100 & 948 & 325 & 2,30 & & \\
\hline $\begin{array}{l}\text { Çorum } \\
\text { (Maden 2) }\end{array}$ & CR-39 & 29 & $42-60$ & $\sim 90$ & 505 & 216 & 1,60 & & [60] \\
\hline $\begin{array}{l}\text { Çorum } \\
\text { (Maden 3) }\end{array}$ & & 33 & $42-60$ & $\sim 60$ & 549 & 286 & 2,00 & & \\
\hline $\begin{array}{l}\text { Manisa } \\
\text { (Soma) }\end{array}$ & LR-115 & & 10ay & 32,5 & 321,2 & & & & {$[61]$} \\
\hline
\end{tabular}

(D:S: Dedektör sayııını (adet), Ö.S: Ölçüm süresini (aksi belirtilmediği durumlar için gün olarak),

Y: Yaz, B: Bahar mevsimini, $\times 2$ ve $\times 3$ ise ölçümlerin 2 ve 3 mevsim için tekrarlandığını göstermektedir) 
uyumlu, ancak diğer 3 müessese için (2002 yılı ölçümleriyle) elde edilen radon düzeylerinden [49-51] daha düşüktür. TTK, 2002 yılından sonra işletmelerindeki havalandırma koşullarını iyileştirmiştir. Bu iyileştirmenin madenlerdeki atmosferik radon seviyelerini azaltıcı yönde bir etkisinin olduğu, söz konusu ölçüm sonuçlarıyla tutarlı bir biçimde açıklanabilir. Başka bir çalışmada, Kozlu, Karadon ve Üzülmez yeraltı maden ocaklarındaki 15 ölçüm noktasında kısa -dönem radon ölçümü ile beraber doğal ${ }^{226} \mathrm{Ra},{ }^{232} \mathrm{Th}$ ve $40 \mathrm{~K}$ radyonüklidlerine ait aktivite konsantrasyonu tayinleri, yüksek çözünürlüklü bir gama-ışını spektrometresi kullanılarak yapılmıştır [57]. Aytekin ve arkadaşları da 2009 yılında, Üzülmez işletmesine ait ${ }^{226} \mathrm{Ra},{ }^{232} \mathrm{Th}$ ve $40 \mathrm{~K}$ aktivite konsantrasyonlarının araştırıldığı bir radyolojik çalışma gerçekleştirmişlerdir [58].

Kütahya linyit madenlerinin incelendiği bir çalışmada, Tunçbilek, Ömerler ve Eynez işletmelerinde gerçekleştirilen radon konsantrasyon ölçümlerinden elde edilen sonuçlar ICRP ve TAEK'in eylem seviyelerine göre değerlendirilmiş ve sonuçların eylem seviyelerinin çok altında olduğu rapor edilmiştir [59]. Diğer bir çalışmada, Çorum ilinin iki farklı ilçesinde faaliyet gösteren 3 farklı yeraltı kömür ocağında radon yoğunluk ölçümleri yapılmış ve her bir madene 30 civarında CR-39 iz dedektörü yerleştirilerek 42 ile 60 gün arasında ölçümler alınmıştır. Elde edilmiş olan değerlerin, TAEK tarafından belirlenmiş olan sınır değerin altında olduğu sonucuna varılmıştır [60].

Manisa Soma maden ocaklarında Haziran 2013 ile Nisan 2014 arasında yapılan bir çalışmada ise, radon ölçümü için LR-115 Tip II nükleer iz kazıma dedektörleri kullanılarak 9 istasyon için ölçümler gerçekleştirilmiş ve çalışma boyunca dedektörler periyodik olarak yenileri ile değiştirilmiştir. Maden ocaklarında, $32,5 \mathrm{~Bq} / \mathrm{m}^{3}$ değerinden $321,2 \mathrm{~Bq} / \mathrm{m}^{3}$ 'e kadar değişen radon konsantrasyonları ölçülmüştür. Ölçüm sonuçları için TAEK tarafından belirle- nen limitin aşılmadığı sonucuna ulaşılmıştır [61].

Tablo 4'de Türkiye'deki kömür madenleri için günümüze kadar yapılan radon ölçümleri ve elde edilen sonuçlar özetlenmektedir. Ölçüm yapılan yer, kullanılan yöntem, ölçüm için kullanılan dedektör sayıları, en düşük ve en yüksek radon ölçümleri ve ölçümlerden elde edilen ortalama değerler, maruz kalınacak yıllık doz düzeyleri ile bilgiler, söz konusu çalışmalarda rapor edildiği şekliyle Tablo 4’de bir araya getirilmiştir. Genel olarak değerlendirildiğinde, Türkiye kömür madenlerindeki radon düzeylerinin dünya ölçeğinde kömür madenleri için verilen ortalamalarla uyumlu olduğu ve atmosferik radon konsantrasyonu ortalamalarının TAEK'in iş yerleri için belirlediği $1000 \mathrm{~Bq} /$ $\mathrm{m}^{3}$ ’ük limiti [23] aşmadığı söylenebilir.

\section{TARTIŞMA VE SONUÇ}

Radonun akciğer kanserine yol açabilmesi bakımından taşıdığı yüksek risk, ocaklarda bu gaza maruz kalan maden çalışanları için göz ardı edilemeyecek bir problemdir. Maden işletmelerindeki radon seviyeleri bilinmelidir. Madenci sağlıyla yakından ilişkili olan bu önemli konu, 20. yüzyılın başlarından beri yürütülen atmosferik radon konsantrasyonu ölçümleriyle birlikte yoğun olarak çalışılmaktadır.

Kömür madenlerindeki atmosferik radon düzeyleri, jeolojik yapı, ocak ortam parametreleri ve madencilik faaliyetlerine bağlı olarak işletmeden işletmeye değişiklik gösterebilir. Diğer madenlerle kıyaslandığında, kömür madenlerindeki radon konsantrasyonları genellikle çok daha düşük seviyelerdedir (102 Bq/m³ mertebesindedir). Radon solunması nedeniyle alınacak yıllık etkin dozun kömür madenlerinde çalışanlar için $0,7 \mathrm{mSv} / \mathrm{yll}$ düzeyinde ve uranyum madeni haricinde çalışan diğer madenciler için $2,7 \mathrm{mSv} / \mathrm{yl}$ civarında olduğu 2000 yılı UNSCEAR raporuyla ortaya konmuştur. Radona maruziyet nedeniyle müsaade edilebilecek doz düzeylerine ait limitler, ICRP tarafindan 3-10 
$\mathrm{mSv} / \mathrm{y}$ ıl olarak belirlenmiştir. $3 \mathrm{mSv} / \mathrm{yl}$ 'lık alt sınırın aşılması halinde müdahalede bulunulabileceği, ancak $10 \mathrm{mSv} /$ yıl'lık üst sınırın aşıldığı durumlarda müdahalenin zorunlu olduğu öngörülmüştür. Kömür madenleri için kabul edilen 0,7 mSv/yıl'lık ortalama değer, ICRP'nin tavsiye ettiği alt müdahale limitinden oldukça düşüktür.

Türkiye kömür madenlerindeki radon araştırmaları nispeten daha yeni tarihlidir (saha ölçümleri 1990’lı yıllarda başlamıştır). Günümüze dek gerçekleştirilmiş sınırlı sayıdaki çalışmalardan, ülkemiz kömür madenlerindeki atmosferik radon seviyelerinin TAEK'in belirlediği limitin $\left(1000 \mathrm{~Bq} / \mathrm{m}^{3}\right)$ altında olduğu sonucu rahatlıkla çıarılabilir. Mevcut araştırmaların büyük bir kısmı TTK taşkömürü işletmelerine odaklanmıştır. En yüksek radon düzeyleri; 2005 yılından önce TTK'ya ait Kozlu, Karadon ve Üzülmez işletmelerinde gözlemlenmişse de; aynı havza için daha sonraki tarihlerde yapılan diğer çalışmalar, işletmelere ait havalandırma koşullarının iyileştirilmesiyle karbonifer penceresindeki madenlerde radon düzeylerinin düştüğüne işaret etmektedir. Kömür madencilerimizin radon nedeniyle maruz kaldıkları yıllık etkin dozların (2002 yılında Kozlu, Karadon ve Üzülmez işletmeleri için yapılan ölçümler hariç) dünya geneli için verilen ortalamaya yakın düzeylerde değiştiği ve ICRP'nin $3 \mathrm{mSv} / \mathrm{yll}$ 'lık alt müdahale limitinden daha düşük olduğu görülmektedir. Türkiye'deki kömür madenlerinde çalışanlar için radon nedeniyle karşı karşıya kalınan radyolojik riskin kabul edilebilir düzeyde olduğu söylenebilir. Ancak kömür madenlerindeki bu riskin mümkün olduğunca aşağıya çekilmesi gerekmektedir. Alınabilecek en etkin önlemlerin belirlenip uygulanabilmesi için madencilik faaliyetlerinin yürütüldüğü alanlarda sürekli atmosferik radon ölçümlerinin yapılması, radon ile ocak ortam parametreleri arasındaki ilişkilerin araştırılması ve ayrıca maden çalışanlarının kişisel radon dozimetreleri ile takip edilerek konu hakkında bilgilendirilmeleri son derece yararlı olacaktır.

\section{AÇIKLAMALAR}

Bu çalışma, Havva Akgönül'ün yüksek lisans tezinin bir parçasıdır. Yazarlar; bu çalışmanın gerçekleşebilmesi adına, Zonguldak Bülent Ecevit Üniversitesi'ne ait 2006-70-0101 nolu projeden elde ettikleri ölçüm verilerini ve konu hakkındaki bilgilerini paylaşan proje ekibine, proje desteği sağlayan Zonguldak Bülent Ecevit Üniversitesi'ne, saha çalışmalarındaki katkılarından dolayı TTK personeline ve ayrıca dedektör analizleri için SANAEM Sağlık Fiziği çalışanlarına teşekkür ederler.

\section{KAYNAKLAR}

[1] UNSCEAR, United Nations Scientific Committee on the Effects of Atomic Radiation, Exposures from Natural Radiation Sources Annex B, 117-118, New York, USA, 2000.

[2] Sabol, J., \& Weng, P.S. Introduction to Radiation Protection Dosimetry: World Scientific Publishing, 300, Singapore, 1995.

[3] NCRP, Report. Measurements of Radon and Radon Daughters in Air, No.97, p.174, 1988.

[4] Olsson, M., \& Tengström, J., Radon Presence and Remedial Measures in Europe and the USA. Thesis for the Degree of Master of Science. Physics and Engineering Physics Subatomic Physics Göteborg University Chalmers University of Technology Göteborg, 2004, Sweden.

[5] Durrani, S.A., \& Iliç, R., Radon Measurements by Etched Track Detectors: Applications in Radiation Protection, Earth Sciences and the Environment, World Scientific Publishing, New Jersey, U.S.A., p.387, 1997.

[6] İnternet: George, A. C., World History of Radon Research and Measurement from the Early 1900's to Today. Historical Evolution of Radon Measure- 
ments, 2007. https://www.researchgate.net/ publication/234912804 World History Of Radon Resear ch And Measurement From The Early 1900's To Today adresinden 14.06.2017 tarihinde erişildi.

[7] Rutherford, E., A Radio-Active Substance Emitted from Thorium Compounds. Philos. Mag., 49, 1-14, 1900.

[8] Dorn, E., Die Von Radioaktiven Substanzen Ausgesandte Emanation. Abhandlungen Der Naturforschenden Gesellschaft (Halle), 23, 1-15, 1900.

[9] Elster, V. J., \& Geitel, H. Electric Leakage in Enclosed Volume of Air. Physikalische Zeitscher, 2, 590593, 1901.

[10] Qureshi, A. A., Kakar, D. M., Akram, M., Khattak, N. U., Tufail, M., Mehmood, K., \& Khan, H. A., Radon Concentrations in Coal Mines of Baluchistan, Pakistan. Journal of Environmental Radioactivity, 48 (2), 203-209, 2000.

[11] UNSCEAR, United Nations Scientific Committee on the Effects of Atomic Radiation Report to the General Assembly, with annexes. United Nations Sales Publication No.E.77.IX. 1. New York, 1977.

[12] Bale, W.F., Hazards Associated with Radon and Thoron. Memorandum to the Files March 14, 1951. Health Phys 38, 1062-1066, 1980.

[13] BEIR VI, Health Effects of Exposure to Radon. National Academy Press. Washington, D.C., 1999.

[14] IAEA, International Atomic Energy Agency. Radiation, People and the Environment. IAEA/PI/A.75/04 $-00391,15-17,2004$.

[15] UNSCEAR, United Nations Scientific Committe on the Effects of Atomic Radiation Report to the General Assembly, with annexes: Sources, Effects and Risks of Ionizing Radiation. United Nations Sales Publication No: E.88.IX.7. New York, 1988.

[16] Ding, L., Getz, G., Wheeler, D. A., Mardis, E. R., McLellan, M. D., Cibulskis, K., \& Fulton, L., Somatic Mutations Affect Key Pathways in Lung Adenocarcinoma. Nature, 455(7216): 1069-75, 2008.
[17] ICRP, International Commission on Radiological Protection, Lung Cancer Risk From Radon and Progeny, ICRP Publication No:115, Annual ICRP 40 (1), 2010.

[18] EPA, Environmental Protection Agency. Citizen's Guide to Radon, U.S. EPA, 402-K02-006, 11-16, 2005 .

[19] WHO, WHO Handbook on Indoor Radon: A Public Health Perspective. WHO Press, Geneva, 2009.

[20] İnternet: EPA, EPA Assessment of Risks from Radon in Homes, EPA Document EPA 402-R-03-003, 2003. http://www.epa.gov/Radon/pdfs/402-r-03003.pdf. adresinden 8.03.2009 tarihinde erişildi.

[21] ICRP, International Commission on Radiological Protection. Radiological Protection Against Radon Exposure, ICRP Publication No:126. Annual ICRP 43(3), 2014.

[22] European Commission (EC), Laying Down Basic Safety Standards for Protection Against the Dangers Arising from Exposure to Ionising Radiation, Brussels, 593, 2011.

[23] Resmi Gazete, (24.03.2000 Tarihli ve 23999 Sayılı Resmi Gazetede Yayımlanan Radyasyon Güvenliği Yönetmeliğinin, 29 Eylül 2004 Tarih ve 25598 Sayılı Resmi Gazete'de Yayımlanan Radyasyon Güvenliği Yönetmeliğinde Değişiklik Yapılmasına Dair Yönetmelik ile Değişik 37. maddesi), 2004.

[24] Sabol, A., Berka, Z., \& Vognar, M., Study of Radon Concentration Behaviour in Tunnel Complex Under Vitkov Hill in Prague, in: Proceedings of European Conference on Protection Against Radon at Home and at Work, Part II, pp. 203-207, 1997.

[25] Madden, J.S., Personal Monitoring of Tour Guides in Irish Show Caves, in: Proceedings of European Conference on Protection Against Radon at Home and at Work, Part II, Prague, pp. 123-128, 1997.

[26] Szerbin, P., Radon and Exposure Levels in Hungarian Caves, Health Physics, 71(3), 362-369, 1996.

[27] Eicker, H. \& Zimmermayer, G., Radon Measurements and Valuation in German Hard Coal Un- 
derground Mines. In: Proc. Int. Conf. on Radiation Hazards in Mining. Soc. Min. Eng. Golden, Colarado, October 1981 (New York) 636-641, 1981.

[28] Chruscielewski, W., Zorawski, A., Olszewski, J., \& Dormanski, T., Radon Concentrations in Air of Polish Underground Coal Mines. In: Proc Int. Conf. on Occupational Radiation Safety in Mining, Toronto. October 1984 297-301, 1985.

[29] Edlin, D. W., Crawford, N. P. \& Dodgson, J., Radon and Thoron Daughter Working Levels in British Coal Mines. Ann. Occup. Hyg. 28 (3), 315-320, 1984.

[30] Duggan, M.J., Howell, D.M., \& Soilleux, P.J., Concentration of Radon-222 in Coal Mines in England and Scotland Nature 219, 1149, 1968.

[31] Kobal, I., Vaupotič, J., Udovč, H., Burger, J., \& Stropnik, B., Radon Concentrations in the Air of Slovene (Yugoslavia) Underground Mines. Environment International, 16(2), 171-173, 1990.

[32] Vishnuprasad Rao, K., Linga Reddy, B., Yadagiri Reddy, P., Ramchander, R.B., \& Rama Reddy, K., Airborne Radon and its Progeny Levels in the Coal Mines of Godavarikhani, Andhra Pradesh, India. Journal of Radiological Protection, 21(3): 259-68, 2001.

[33] Schery, S. D., Gaeddert, D. H., Wilkening, M. H., Factors Effecting Exhalation of Radon from Gravelly Sandy Loam J. Geophys. Res. 89(D5): 7299-7309, 1984.

[34] ICRP, International Commission on Radiological Protection. Protection Against Radon-222 at Home and at Work. ICRP Publication No:65, Annual ICRP 23(2), 1993.

[35] Veiga, L. H. S., Melo, V., Koifman, S., \& Amaral, E. C. S., High Radon Exposure in a Brazilian Underground Coal Mine. Journal of Radiological Protection, 24(3), 295, 2004.

[36] Chen, C. C., Weng, P. S., Chu T. C. J., \& Radiat Res., Radon Concentration in Two Largest Cities in Semitropical Taiwan. Jun; 33(2): 133-40, 1992.
[37] Page, D., \& Smith, D. M., The Distribution of Radon and its Decay Products in Some UK Coal Mines, Radiation Protection Dosimetry, 45(1-4), 163-166, https://doi.org/10.1093/rpd/45.1-4.163, 1992.

[38] Ghiassi-Nejad, M., M. Beitollahi, M., Fathabadi, N., $\&$ Nasiree, P. Exposure to ${ }^{222} \mathrm{Rn}$ in Ten Underground Mines in Iran. Radiation protection Dosimetry, 98(2), 223-225, 2002.

[39] Veiga, L. H., Amaral, E. C., Colin, D., \& Koifman, S., A Retrospective Mortality Study of Workers Exposed to Radon in a Brazilian Underground Coal Mine. Radiation and Environmental Biophysics, 45 (2), 125-134, 2006.

[40] Da Silva, A. L. M. A., de Eston, S. M., Iramina, W. S., \& Francisca, D. D., Radon in Brazilian Underground Mines. Journal of Radiological Protection, 38(2), 607, 2018.

[41] Liu, F.D., Pan, Z.Q., Liu, S.L., Chen, L., Ma, J.Z., Yang, M.L., \& Wang, N.P., The Estimation of the Number of Underground Coal Miners and the Annual Dose to Coal Miners in China. Health Physics, 93(2), 127-132, 2007.

[42] Nhan, D. D., Fernando, C. P., Ha, N. T. T., Long, N. Q., Thuan, D. D., \& Fonseca, H. Radon ( $\left.{ }^{222} \mathrm{Rn}\right)$ Concentration in Indoor Air Near the Coal Mining Area of Nui Beo, North of Vietnam. Journal of Environmental Radioactivity, 110: 98-103, 2012.

[43] Bossew, P., Radon: Exploring the Log-Normal Mystery. Journal of Environmental Radioactivity, 101 (10), 826-834, 2010.

[44] Portola, V. A., Torosyan, E. S., \& Antufeyev, V. K., Radon Emission from Coal Mines of Kuzbass Region. In IOP Conference Series: Materials Science and Engineering, 127(1), p.012021. IOP Publishing, 2016.

[45] Tchorz-Trzeciakiewicz, D. E., \& Parkitny, T. Radon As a Tracer of Daily, Seasonal and Spatial Air Movements in the Underground Tourist Route "Coal Mine" (SW Poland). Journal of Environmental Radioactivity, 149: 90-98, 2015.

[46] Fan, D., Zhuo, W., ve Zhang, Y., Occupational 
Exposure to Radon in Different Kinds of NonUranium Mines. Radiation Protection Dosimetry, 170(1-4), 311-314, 2016.

[47] Küçüktaş, E., Maden Ocaklarındaki Radyonüklid Konsantrasyonlarının Birikimi Etkileyen Parametrelere Bağlı Olarak Ölçülmesi, Maruz Kalınan Dozların Analitik Bir Yöntem Geliştirilerek Hesaplanması. Doktora Tezi, Ege Üniversitesi, Nükleer Enerji Enstitüsü, 1996, İzmir.

[48] Yener, G., Küçüktaş, E., Concentrations of Radon and Decay Products in Various Underground Mines in Western Turkey and Total Effective Dose Equivalents, Analyst, 123(1): 31-34, 1998.

[49] Fişne, A., Yeraltı Madenlerinde Radon Gazı Konsantrasyon Seviyelerinin Belirlenmesi ve İşçi Sağlığı Üzerine Etkilerinin Araştırılması. Yüksek Lisans Tezi, İstanbul Teknik Üniversitesi, Fen Bilimleri Enstitüsü, 2002, İstanbul.

[50] Fişne, A., Ökten, G., \& Çelebi, N., Türkiye Taşkömürü Kurumu (TTK) Yeraltı Maden Ocaklarında Radon Gazı Yayılımının İncelenmesi, Türkiye 14 Kömür Kongresi, Zonguldak, Türkiye, Bildiri Kitabı, 193-202, 2004.

[51] Fişne, A., Ökten, G., \& Çelebi, N., Radon Concentration Measurements in Bituminous Coal Mines. Radiation Protection Dosimetry, 113(2): 173-177, 2005.

[52] Baldık, R., Aytekin, H., Çelebi, N., Ataksor, B., \& Taşdelen, M., Radon Concentration Measurements in the Amasra Coal Mine, Turkey. Radiation Protection Dosimetry, 118(1): 122-125, 2006.

[53] Baldık, R., Aytekin, H., \& Çelebi, N., Radon Fluctuations in the Armutçuk Coal Mine, Turkey. Fresenius Environmental Bulletin, 18(1): 87-91, 2009.

[54] Baldık, R., \& Aytekin, H., Zonguldak Taş Kömürü Havzasında Yapılmış Radon Gazı Ölçümlerinin Değerlendirilmesi. Karaelmas İş Sağlığı ve Güvenliği Dergisi, 1(1): 1-7, 2017.

[55] Yılmaz, A., Kürkçüoğlu, M.E., Haner, B., Nükleer İz Dedektörlerinin Konumlarının Radon Konsantrasyonu Ölçümleri Üzerine Etkisi. X. Ulusal Nükleer Bi- limler ve Teknolojileri Kongresi, Muğla, Türkiye, 0609 Ekim 2009, Bildiri Tam Metinleri Kitabı Cilt II, 256-262, 2009.

[56] Akgönül, H., Türkiye Batı Karadeniz Bölgesi Karbonifer Penceresi Taşkömürü Ocaklarında Yıllık Atmosferik Radon Konsantrasyonu Ölçümleri, Yüksek Lisans Tezi, Süleyman Demirel Üniversitesi, 2019, Isparta.

[57] Emirhan, M.E., \& Özben C.S., Assessment of Radiological Risk Factors in the Zonguldak Coal Mines. Journal of Radiological Protection, 29(4): 527-534, 2009.

[58] Aytekin, H., Baldık, R., An Investigation on the Radiological Influence of an Underground Coal Mine in Zonguldak Basin, Turkey. Fresenius Environmental Bulletin, 18(4): 468-473, 2009.

[59] Çile, S., Altınsoy, N., \& Çelebi, N., Radon Concentrations in Three Underground Lignite Mines in Turkey. Radiation Protection Dosimetry, 138(1): 78-82, 2009.

[60] Uzbey, S., Tel, E., Aytekin, H., \& Albayrak, N., Çorum İli Yeraltı Kömür Ocaklarında Radon Yoğunluğu Ölçümü. Karaelmas Fen ve Mühendislik Dergisi, 3(1): 1-5, 2013.

[61] Bölükbaş, M., Manisa Soma Bölgesi Maden Ocakları ve Çevre Binalarında Radon Konsantrasyonunun İncelenmesi, Yüksek Lisans Tezi, Ege Üniversitesi, 2015, İzmir. 